\title{
MEMAHAMI DAN MENGELOLA DAMPAK PARIWISATA
}

\author{
Victor Bangun Mulia
}

Diploma IV Manajemen Perhotelan, Politeknik Internasional Bali

Jln. Pantai Nyanyi, Tabanan, Bali, Indonesia

Victorbm77@gmail.com

Received: June, 2021

Accepted: June, 2021

Published: July, 2021

\begin{abstract}
This paper aims at providing information and understanding about the impacts of tourism on the economic sector, sociocultural living, and environmental. Globally, tourism is considered as one of the leading sectors contributing huge numbers in the global GDP. Now wander many countries rely on the tourism sector as the source of income and many countries do their best to develop the tourism potency had. The rapid dan massive development of tourism in the world brings both negative and positive aspect to those three sectors; economic, socio-cultural, and environmental. The negative impacts of tourism should be anticipated and managed well by the government, stakeholder, and community. One thing that can be done is by implementing visitor management that is an administrative action to maintain the environment, socio-cultural living, and economic sector without neglecting the satisfaction of tourists. Visitor management is implemented by balancing the tourist' needs, local community's needs, stakeholders' needs, and the current situation and potency of the destination. The implementation visitor management leads to the sustainable tourism.
\end{abstract}

Keywords: tourism impacts, visitor management, sustainable tourism

\begin{abstract}
Abstrak
Tulisan ini bertujuan untuk memberikan informasi dan pemahaman mengenai dampak pariwisata terhadap sektor ekonomi, kehidupan sosial dan budaya, serta lingkungan. Secara global, pariwisata dapat dikatakan sebagai salah satu sektor yang memimpin yang memberikan kontribusi besar pada GDP global. Tidak mengherankan jika banyak negara menggantungkan perekonomian mereka dari pariwisata dan banyak negara berusaha untuk mengembangkan potensi wisata yang mereka miliki. Perkembangan yang cepat dan masif berdampak negatif dan positif pada sektor ekonomi, kehidupan sosial dan budaya, serta lingkungan. Dampak buruk parwisata harus diantisipasi dan dikelola dengan baik oleh pemerintah, pelaku wisata, dan masyarakat. Salah satu yang bisa diterapkan adalah visitor management yang merupakan langkah administratif untuk menjaga kelestarian lingkungan, sosial budaya, dan ekonomi tanpa mengesampingkan kepuasan wisatawan. visitor management dilakukan dengan menyeimbangkan kebutuhan wisatawan, kebutuhan masyarakat, kebutuhan pelaku wisata, dan situasi lingkungan. Implementasi visitor management membawa pada parwisata berkelanjutan.
\end{abstract}

Kata Kunci: dampak pariwisata, visitor management, pariwisata berkelanjutan 


\section{PENDAHULUAN}

Pariwisata merupakan sektor yang saat ini tengah berkembang dan bahkan menjadi salah satu fenomena global. Dalam perkembangannya, sektor pariwisata melibat berbagai sektor, seperti ekononomi, sosial, kesehatan, dan sebagainya serta melibatkan semakin banyak orang dan masyarakat. United Nations World Tourism Organization (UNWTO) (2016) dalam Understanding Basic Glossary of Tourism bahkan menyatakan bahwa pariwisata merupakan fenomena sosial, budaya, dan ekonomi. Pernyataan UNWTO tersebut menunjukkan bahwa sektor pariwisata bukanlah sektor tunggal. Namun pariwisata terdiri dari berbagai sektor lain yang saling mendukung. Melihat perkembangan sektor pariwisata dari waktu ke waktu, pariwisata dapat dikatakan sebagai salah satu industri terbesar di dunia (Tovmasyan, 2016). Ini didukung oleh catatan UNWTO (2020) yang mengemukakan bahwa pada tahun 2019 terdapat 1.5 miliar kunjungan wisatawan internasional di seluruh dunia dengan total kenaikan sebesar 4\% dari tahun sebelumnya.

Di Indonesia sendiri, sektor pariwisata merupakan salah satu penyumbang devisa negara terbesar. Menurut Laporan Akhir Kajian Dampak Pariwisata Terhadap Perekonomian Indonesia yang dirilis oleh Kementerian Pariwisata dan Ekonomi Kreatif (Kemenparekraf) Republik Indonesia tahun 2018, pada tahun 2017 kontribusi sektor pariwisata sebesar USD 4,23 yang lebih tinggi dibandingkan tahun 2016. Pada sumber yang sama dikemukakan pula bahwa sektor pariwisata menyerap sebanyak 12,3 juta tenaga kerja. Data statistik tersebut menunjukkan peranan sektor pariwisata dalam pertumbuhan perekonomian Indonesia. Namun, jika dibandingkan dengan pariwisata negara lain di kawasan Asia Tenggara, sektor pariwisata Indonesia dapat dikatakan masih tertinggal dari segi lingkungan, infrastruktur, kebijakan, serta dampaknya pada perekonomian (Kemenparekraf, 2018).

Perkembangan sektor pariwisata yang begitu cepat dan masif ini perlu mendapat perhatian lebih dari seluruh elemen yang terlibat di dalamnya. Pariwisata layaknya pisau bermata dua, memiliki dua sisi yang patut diketahui dan dipahami oleh publik. Selain memberikan kontribusi positif pada pertumbuhan ekonomi, pariwisata juga memiliki sisi gelap yang patut diantisipasi. Dampak buruk pariwisata dapat dikatakan sebagai konsekuensi dari perkembangan pariwisata di suatu daerah atau bahkan di dunia. Dampak negatif pariwisata ini dapat ditemui pada sektor ekonomi, sosial dan budaya, serta lingkungan. Tiga elemen tersebut merupakan elemen yang memiliki hubungan begitu erat dengan dunia pariwisata. Sektor ekonomi merupakan salah satu dari tiga elemen yang erat kaitannya dengan dunia pariwisata mengingat dalam dunia pariwisata terjadi perputaran uang dan bahkan transaksi bisnis. Selain ekonomi, elemen lain yang berkaitan erat dengan sektor pariwisata adalah sosial dan budaya. Pariwisata melibatkan interaksi antar manusia di dalamnya yang turut membawa budaya masing-masing sehingga ini akan mempengaruhi pola budaya dan interaksi sosial yang ada serta perkembangannya. Elemen terakhir adalah lingkungan yang merupakan salah satu daya tarik wisata yang dimiliki oleh suatu daerah. Tak jarang terjadi eksploitasi yang berlebihan terhadap lansekap alam untuk kebutuhan pariwisata.

Dalam perkembangannya, muncul istilah overtourism yang mengacu kepada dampak buruk pariwisata pada suatu destinasi pariwisata atau bagiannya yang berpengaruh pada kualitas hidup masyarakat local atau pengalaman wisatawan yang berkunjung (UNWTO, 2018). Berangkat dari definisi tersebut, pariwisata tidak hanya berpengaruh baik, namun juga dapat membawa 
pengaruh atau dampak yang buruk bagi masyarakat, namun juga bagi wisatawan yang berkunjung. Tiga sector atau elemen yang secara langsung menerima dampak buruk pariwisata adalah sector ekonomi, social dan budaya, serta lingkungan. Pada sector ekonomi, secara umum pariwisata memberikan dampak yang positif, namun dampak negative juga tidak dapat dihindari. Salah satu dampak buruk pariwisata terhadap sector ekonomi adalah kebocoran ekonomi atau lebih dikenal dengan nama econonomic leakage. Kebocoran ekonomi sebagai dampak dari pariwisata terjadi ketika hotel, transportasi, dan penunjang pariwisata lainnya dimiliki oleh pemodal asing yang memiliki perusahaan di luar negeri sehingga pendapatan dan seluruh keuntungan akan bergerak ke negara lain (Kumar, et al., 2015).

Tak hanya sector ekonomi, dampak buruk pariwisata juga turut dirasakan pada kehidupan social dan budaya. Sebuah penelitian yang dilakukan di Cina menunjukkan bahwa perkembangan pariwisata menyebabkan munculnya gaya hidup hedonism dan kelambanan dalam bekerja (Zhuang, et al., 2019). Selain itu, dampak pariwisata terhadap

\section{METODE PENELITIAN}

Penelitian ini dilakukan dengan
menggunakan literature research
methodology atau library research. Metodologi ini di Indonesia lebih dikenal dengan penelitian kepustakaan. Literature research methodology merupakan sebuah metodologi penelitian yang tidak melakukan kontak secara langsung dengan objek penelitian, melainkan membuka akses secara tidak langsung ke informasi terkait dengan objek penelitian dari berbagai sumber tertulis (Lin, 2009). Berdasarkan definisi tersebut literature research methodology tidak memerlukan adanya penelitian lapangan untuk mengumpulkan data yang diperlukan untuk menjawab rumusan masalah yang diangkat dalam sebuah penelitian. Peneliti dalam hal ini mengumpulkan literatur atau sumber lingkungan juga menjadi salah satu isu yang hangat dalam pembahasan dan kajian mengenai pariwisata dan lingkungan. Penelitian yang dilakukan di Praia da Cova Redonda, Portugal menemukan bahwa pariwisata memiliki dampak negative terhadap kekayan biodiversitas local akibat pengisian pantai secara artifisial (Nunes, et al., 2020).

Melihat dampak positif sekaligus negatif yang ditimbulkan oleh perkembangan pariwisata di suatu destinasi wisata, maka pengembangan pariwisata seyogyanya dilakukan dengan penuh pertimbangan yang tidak hanya mengacu pada pertumbuhan ekonomi semata, namun juga dampak terhadap kehidupan social budaya serta lingkungan. Tulisan ini mengkaji dan membahas mengenai dampak pariwisata terhadap sector ekonomi, social budaya, serta lingkungan untuk memberikan pemahaman yang lebih mendalam dan kompleks kepada pembaca dan masyarakat. Dengan adanya tulisan ini diharapkan pengembang pariwisata, masyarakat, dan pelaku pariwisata dapat melakukan pengembangan pariwisata secara bijak dan bertanggung jawab

kepustakaan yang terkait dengan objek penelitian untuk kemudian dianalisis sehingga mendapatkan data yang diperlukan.

\section{HASIL DAN PEMBAHASAN}

Pada bagian pembahasan akan dibahas secara detail dan mendalam mengenai dampak positif dan negatif pariwisata serta hal-hal yang perlu diantisipasi dan ditanggulangi sebagai dampak dari perkembangan pariwisata yang begitu pesat dan global.

\subsection{Keterkaitan Antara Sektor Pariwisata dan Ilmu Geografi}

Dunia pariwisata bukanlah sebuah dunia atau ilmu yang berdiri sendiri. Dunia pariwisata dibangun oleh banyak sector dan ilmu-ilmu yang berkaitan, seperti ilmu ekonomi, sosiologi, budaya, 
lingkungan, dan sebagainya. Kontribusi atau sumbangsih dari ilmu-ilmu lainnya menyebabkan dunia pariwisata menjadi sebuah dunia yang kompleks dan dapat dilihat dari berbagai persepktif. Salah satu ilmu yang memiliki keterkaitan yang begitu erat dengan dunia pariwisata adalah geografi (Page, 2019). Geografi merupakan sebuah cabang ilmu yang mempelajari bumi, lingkungan, manusia dan hubungannya dengan manusia lain pada berbagai level dan skala, mulai dari skala internasional hingga regional. Ilmu geografi melakukan eksplorasi pada tempat di seluruh permukaan bumi sehingga pakar geografi mengetahui seluk beluk tempat-tempat di bumi.

Di lain sisi, pariwisata merupakan sebuah dunia yang begitu dinamis yang melibatkan perpindahan manusia atau masyarakat dari satu tempat ke tempat lainnya. Hal tersebut dapat menunjukkan keterkaitan antara ilmu geografi dengan dunia pariwisata. Hasil dari kajian yang dilakukan oleh para pakar geografi dapat menjadi acuan bagi pelaku pariwisata dalam merencanakan dan mengembangkan sebuah destinasi wisata. Ilmu geografi akan menguraikan potensi yang dimiliki oleh suatu daerah, kemudian pariwisata akan mengembangkan potensi yang ada sebagai daya tarik wisata. Selain potensi, geografi juga akan menyajikan informasi dan data mengenai ancaman yang ditemukan di daerah yang akan menjadia acuan bagi pengembang pariwisata untuk mengantisipasi hal-hal yang tidak diinginkan.

Selain hal tersebut, geografi juga membantu pelaku pariwisata untuk melihat pergerakan wisatawan serta trend pariwisata sehingga pelaku pariwisata memiliki pemahaman dasar tentang operasional pariwisata di suatu daerah. Untuk memahami pergerakan wisatawan serta trend yang ada, geografi menggunakan dua teknik yang dapat memberikan informasi yang relevan. Teknik pertama adalah melakukan analisis serta pemetaan pergerakan wisatawan dari daerah asal ke daerah tujuan. Analisis dan pemetaan yang dilakukan dapat memberikan informasi dan data mengenai wisatawan dari negara apa saja yang berkunjung. Dengan mengetahui asal wisatawan, maka pelaku pariwisata dapat mempersiapakn atraksi wisata, makanan, akomodasi yang sesuai dengan minat wisatawan. Teknik kedua yang dapat dilakukan adalah memahami dan menganalisis pola aktifitas wisatawan untuk dapat mengetahui trend pariwisata.

Selain membantu memahami dinamisnya dunia pariwisata, ilmu geografi juga turut membantu dalam mengidentifikasi dampak yang ditimbulkan oleh perkembangan pariwisata. Dengan adanya identifikasi terhadap potensi dampak pariwisata, maka dapat dilakukan penilaian dan pengukuran dampak pariwisata untuk selanjutnya diambil tindakan atau Langkah penanggulangan atau antisipasi. Informasi dan data yang diperoleh oleh para pakar geografi tersebut dapat membantu pelaku pariwisata untuk dapat memahami dinamisnya dunia pariwisata. Tidak hanya geografi, cabang ilmu lainnya juga berperan sangat penting dalam perkembangan ilmu pariwisata. Hal ini mengingat dunia pariwisata melibatkan banyak sector dan ilmu di dalamnya.

\subsection{Dampak Pariwisata terhadap Sektor Ekonomi}

Seperti yang telah dipaparkan pada bagian pendahuluan bahwa sector ekonomi merupakan satu dari 3 sektor yang menerima dampak dari perkembangan pariwisata di suatu daerah atau negara. Tercatat bahwa pada tahun 2019, sector pariwisata menyumbang sebesar US\$ 8.9 triliun atau $10.3 \%$ terhadap GDP dunia (World Travel \& Tourism Council, 2020). Selain itu Worl Travel \& Tourism Council (2020) juga mencatat bahwa pariwisata membuka kesempatan sebesar 330 juta pekerjaan dan menyerap US\$948 milyar invetasi modal. 
Melihat kontribusi dan dampak perkembangan pariwisata terhadap sector ekonomi suatu negara atau daerah, maka tidak mengherankan jika pemerintah suatu negara maupun daerah melihat perkembangan pariwisata sebagai suatu kesempatan dan peluang untuk membantu meningkatkan dan meregenerasi pertumbuhan ekonomi suatu negara. Dunia pariwisata sering kali diasosiasikan sebagai peluang kerja dan sumber pendapatan bagi perekonomian suatu daerah atau negara sehingga ini menjadi alat bagi sector public dan swasta untuk mendapat dukungan masyarakat dalam mengembangkan suatu destinasi wisata.

Berikut ini merupakan beberapa manfaat atau dampak ekonomi yang dituju dari perkembangan pariwisata (Hall \& Lew, 2009).

a. Diversifikasi dan stabilisasi ekonomi Sector pariwisata dianggap sebagai alternatif yang dapat membantu pertumbuhan ekonomi suatu negara atau daerah, khususnya ketika penurunan pertumbuhan ekonomi terjadi. Ini sering kali dijumpai pada negara atau daerah yang memiliki sumber daya tambang dan kayu yang tinggi. Pertambangan merupakan salah satu sector ekonomi yang tidak terbarukan sehingga saat sumber daya habis digali, maka pertambangan tersebut harus ditutup. Efek dari penutupan pertambangan tersebut berimbas pada keadaan perekonomian suatu negara atau daerah yang otomatis akan mengalami penurunan. Oleh karena itu, perkembangan dunia pariwisata dapat menjadi sumber perekonomian yang dapat membawa stabilitas ekonomi.

b. Peningkatan pajak untuk membantu mendanai pemerintah

Sector pariwisata merupakan salah satu penyumbang pajak terbesar bagi negara melalui hotel, akomodasi wisata, destinasi wisata, usaha perjalanan, dan sebagainya. Pajak yang dibayarkan sector pariwisata kepada pemerintah juga akan digunakan untuk mendukung pembangunan infrastruktur dan pengembangan sumber daya manusia di bidang pariwisata.

Hal yang sama juga dikemukakan oleh Page (2019) yang menyebutkan empat dampak positif utama dari perkembangan pariwisata terhadap sector ekonomi suatu daerah atau negara. Empat dampak tersebut adalah sebagai berikut.

a. Membangkitkan perekonomian local atau daerah

Kunjungan wisatawan merupakan suatu rangsangan terhadap bangkitnya perekonomian daerah. Dalam suatu destinasi wisata terjadi perputaran uang yang begitu besar sehingga dapat menjadi stimulus bagi perekonomian daerah.

b. Terbukanya lapangan kerja baru Dunia pariwisata membuka berbagai lapangan kerja baru bagi masyarakat. Secara tidak langsung ini juga dapat meningkatkan perekonomian daerah.

c. Terjadinya perbaikan struktur dan stabilitas ekonomi daerah

Hal ini serupa dengan yang dikatakan oleh Hall \& Lew (2009) tentang potensi dunia pariwisata sebagai salah satu alternatif untuk membangun stabilitas ekonomi suatu daerah atau negara.

d. Meningkatkan praktik kewirausahaan Kebutuhan wisatawan akan akomodasi, transportasi, makanan, dan hal-hal lain selama berkunjungung menjadi pemacu munculnya jiwa dan praktik kewirausahaan di suatu daerah.

Meskipun perkembangan pariwisata dapat menjadi salah satu alternatif atau bahkan sumber pendapatan atau perekonomian suatu daerah atau negara, Page (2019) meyakini bahwa dunia pariwisata bukanlah merupakan sumber pendapatan yang stabil mengingat loyalitas wisatawan terhadap suatu destinasi wisata tidak dapat dijamin. Page dan Hall (2003) dikutip dari Page 
(2019) menyebutkan lima alas an mengapa dunia pariwisata bukanlah sumber pendapatan yang stabil.

a. Pariwisata merupakan industri yang berubah-ubah dan dinamis serta bersifat musiman sehingga trend maupun lapangan kerja yang ditawarkan juga berubah-ubah. Pekerjaan dalam bidang pariwisata sering dihubungkan dengan pekerjaan yang tidak stabil. Dunia pariwisata dipengaruhi oleh berbagai kondisi, situasi, maupun stabilitas politik suatu negara. Contoh dari ketidakstabilan dunia pariwisata adalah ketika pandemic Covid-19 muncul. Dunia pariwisata mengalami keterpurukan yang luar biasa.

b. Kebutuhan wisatawan sangat dipengaruhi oleh factor eksternal, seperti politik, cuaca, musim, dan yang lainnya. Destinasi maupun pengelolanya tidak dapat mengendalikan atau mengontrol halhal tersebut.

c. Motivasi wisatawan untuk berwisata sangatlah kompleks dan dipengaruhi oleh variable yang sangat dinamis.

d. Pendapatan dari sector pariwisata sangatlah elastis dan mudah dipengaruhi berbagai factor.

e. Adanya pembangunan destinasi wisata yang memiliki struktur yang sama sehingga tidak memiliki keunikan.

Salah satu ancaman dan dampak buruk dari perkembangan pariwisata terhadap sector ekonomi adalah tourism leakage atau kebocoran ekonomi akibat pariwisata. Tourism leakage dapat diartikan sebagai hilangnya pendapatan dan keuntungan dari perekonomian daerah atau negara sebagai akibat dari adanya kepemilikan property pariwisata, destinasi pariwisata, dan pendukung pariwisata lainnya yang berasal dari luar negeri. Akibatnya pendapatan dan keuntungan dari sector pariwisata tidak dinikmati oleh masyarakat local namun bergerak ke luar negeri dimana perusahaan pemiliki akomodasi, restoran, usaha perjalanan wisata bernaung. Pada tahun 2012, tourism leakage ditemukan di Bali yang merupakan salah satu destinasi terbesar pariwisata dunia (Wiranatha, et al., 2015). Penelitian tersebut menemukan bahwa kebocoran terbesar terjadi pada interntional hotel chain yang berbintang 4 dan 5 yang mengalami kebocoran sebesar 55.31\% sedangkan kebocoran terendah terjadi non-star hotel, yaitu sebesar 2.0\%. Efek dari kebocoran tersebut adalah perekonomian mengalami penurunan karena pendapatan dan keuntungan bergerak ke luar daerah.

Selain siap menghadapi dampak positif dari pariwisata, pelaku pariwisata seyogyanya siap dan paham akan dampak negatif serta resiko dari perkembangan pariwisata terhadap sector ekonomi. Perkembangan pariwisata yang semula ditujukan untuk membangkitkan dan meningkatkan perekonomian daerah dapat berujung pada tourism leakage jika tidak dikelola dengan baik. Untuk menghindari hal tersebut, pemerintah daerah maupun pusat perlu membuat sebuah regulasi yang mengatur tentang isu tersebut guna meningkatkan perekonomian daerah.

\subsection{Dampak Pariwisata terhadap Kehidupan Social dan Budaya}

Kehidupan social dan budaya merupakan elemen lain yang bersinggungan langsung dengan dunia pariwisata sehingga dampak baik maupun buruk pariwisata secara langsung berimbas pada kehidupan social dan budaya di suatu destinasi pariwisata. Page (2019) mengatakan bahwa dunia pariwisata merupakan dampak dari kehidupan social budaya serta memberi dampak pada kehidupan social budaya.

Lebih jauh Pearce (1989) dikutip dari Page (2019) menyebutkan tujuan dampak perkembangan pariwisata terhadap kehidupan sosial dan budaya masyarakat di suatu destinasi wisata.

a. Mendorong terjadinya urbanisasi dimana masyarakat yang tinggal di 
pinggiran kota atau daerah yang tidak berkembang pariwisatanya memilih untuk berpindah atau melakukan migrasi ke daerah urban dimana sektor pariwisata berkembang pesat. Urbanisasi ini terjadi karena tinggi tingkat pendapatan dari sektor pariwisata.

b. Mendorong terjadinya perubahan struktur pekerjaan masyarakat dan munculnya isu ketenagakerjaan, seperti kesetaraan gender, upah rendah, dan lain sebagainya.

c. Terjadinya perubahan pada nilai-nilai sosial yang berkembang di dalam masyarakat.

d. Mendorong terjadinya perubahan pada struktur perumahan masyarakat dimana masyarakat harus pindah untuk mengakomodasi perkembangan dan pembangunan akomodasi pariwisata.

e. Meningkatkan tingkat kriminalitas, khususnya ketika perhelatan besar diadakan.

f. Berpotensi untuk meningkatkan praktik prostitusi dan perjudian untuk mengakomodasi kebutuhan wisatawan.

g. Potensi punahnya bahasa daerah semakin terbuka lebar mengingat adanya kebutuhan komunikasi dalam bahasa internasional.

Dampak atau pengaruh negatif dari perkembangan pariwisata terhadap kehidupan sosial dan budaya di suatu destinasi wisata dapat dikelompokkan menjadi tiga katergori, yaitu overcrowding and loss of amenities for residents, cultural impacts, dan social problems (Urbanus \& Febianti, 2017).

a. Overcrowding and loss of amenities for residents merupakan suatu keadaan dimana masyarakat atau penduduk kehilangan kenyamanan untuk tinggal yang disebabkan oleh tingginya kunjungan wisatawan sehingga tidak ada pembatas antara kehidupan masyarakat lokal dengan wisatawan. Kunjungan wisatawan yang tinggi, di satu sisi, dapat memberikan dampak positif terhadap sektor ekonomi, namun jika ditilik dari segi sosial dan budaya tingginya kunjungan wisatawan menimbulkan kepadatan penduduk dan ketidaknyamanan bagi penduduk lokal. Gambar di bawah menunjukkan padatnya wisatawan yang mengunjungi Santorini.

b. Cultural impacts terjadi akibat adanya komersialisasi budaya sebagai komoditas pariwisata. Setelah adanya komersialisasi budaya untuk tujuan pariwisata, maka budaya tersebut tidak lagi sama. Tanpa disadari, budaya asli mulai terkikis dan termodifikasi sesuai dengan kebutuhan wisatawan.

c. Social problems berkaitan dengan nilai-nilai dan landasan yang dipegang teguh oleh masyarakat dalam menjalankan kehidupan sehari-hari. Dalam penelitian yang dilakukan oleh Urbanus dan Febianti (2017), masyarakat cenderung merubah orientasi mereka pada uang dan financial serta bersikap konsumtif.

Namun perkembangan pariwisata tidak hanya membawa pengaruh negatif terhadap kehidupan sosial dan budaya. Hall dan Lew (2009) menyatakan bahwa perkembangan pariwisata merupakan suatu langkah untuk melakukan konservasi terhadap seni dan budaya di suatu destinasi. Seni dan budaya suatu daerah merupakan daya tarik tersendiri bagi wisatawan sehingga dapat menjadi atraksi wisata yang menarik. Pengelolaan pendapatan dan keuntungan dari sektor pariwisata jika dilakukan dengan baik maka akan menjadi sumber dana untuk melakukan pelestarian budaya dan seni di suatu destinasi.

Seperti halnya pengaruh perkembangan pariwisata terhadap sektor ekonomi, perkembangan pariwisata juga memberikan pengaruh positif dan negatif terhadap kehidupan sosial dan budaya. Jika perkembangan pariwisata di suatu daerah tidak dikelola dengan bijaksana, maka dapat menjadi ancama bagi kelangsungan suatu budaya bahkan dan menjadi permasalahan serius bagi kehidupan sosial masyarakat, 
seperti muncul konflik dan kesenjangan sosial.

\subsection{Dampak Pariwisata terhadap Lingkungan}

Saat ini isu mengenai sustainable tourism atau pariwisata berkelanjutan merupakan topik perbincangan, kajian, dan pembahasan yang hangat. Istilahistilah lain yang mengacu pada parwisata berkelanjutan pun bermunculan, seperti pariwisata hijau atau green tourism dan ecotourism. Memang dunia pariwisata memiliki keterkaitan yang erat dengan lingkungan. Isu ini muncul dikarenakan oleh dampak perkembangan pariwisata yang begitu buruk terhadap lingkungan. Page (2019) mengemukakan beberapa dampak buruk pengembangan pariwisata yang tidak tetap terhadap lingkungan di pesisir.

a. Erosi

b. Penggaraman sumber air tanah yang menyebabkan kurang persediaan air,

c. Pembuangan limbah ke laut dangkal yang memiliki efek buruk terhadap pertumbungan terumbu karang. Gambar di bawah merupakah contoh nyata dari dampak negatif pariwisata terhadap lingkungan yang terjadi di Pantai Kuta, Bali.

Gossling (2002) dikutip dari Hall dan Lew (2009) menyebutkan hal serupa yaitu dampak lingkungan secara global sebagai konsekuensi dari perkembangan dunia pariwisata.

a. Perubahan pada penggunaan lahan Seperti yang dipaparkan pada bagian dampak pariwisata terhadap kehidupan sosial budaya bahwa dunia pariwisata akan mendorong masyarakat untuk melakukan urbanisasi. Oleh karena itu, akan terjadi perubahan pada penggunaan lahan selain perubahan penggunaan lahan untuk keperluan pariwisata, seperti pembangunan hotel, taman rekreasi, dan lain sebagainya.

b. Penggunaan energi dan dampaknya Dunia pariwisata tidak dapat dilepaskan dari penggunaan energi dalam jumlah besar. Salah satu contohnya adalah penggunaan listrik dan air. Penggunaan energi dalam jumlah besar ini patut mempertimbangkan dampak yang ditimbulkan di kemudian hari.

c. Perubahan biota dan kepunahan spesies liar

Pengembangan pariwisata yang tidak bijak dan bertanggung jawa berujung pada punahnya spesies-spesies liar akibat adanya pencemaran lingkungan, seperti pembuangan limbah ke laut yang akan menjadi ancaman bagi biota laut serta pembabatan hutan untuk tujuan pariwisata yang juga turut memberi kontribusi pada kepunahan ekosistem hutan.

d. Penyebaran penyakit

Adanya pergerak secara global menyebabkan mudahnya penyebaran penyakit. Saat ini, pemerintah menutup penerbangan internasional guna mencegah penyebaran Virus Covid-19.

e. Perubahan persepsi tentang lingkungan

Adanya interaksi dan komunikasi global yang terjadi dalam dunia pariwisata akan turut serta mempengaruhi persepsi masyarakat dunia akan isu lingkungan. Isu pariwisata berkelanjutan kemudian lahir dan menjadi pemabahasan dan kajian para pakar pariwisata. Saat ini wisatawan memiliki persepsi yang positif terhadap konsep pariwisata berkelanjutan sehingga mempengaruhi tindakan dan perilaku mereka dalam berwisata (IbnouLaaroussi, et al., 2020).

\subsection{Pengelolaan Pengunjung/ Wisatawan}

Melihat dampak dari perkembangan pariwisata, khususnya dampak negatif yang ditimbulkan, pengembangan dan pengelolaan parwisata di suatu destinasi atau daerah perlu mendapatkan perhatian yang serius dan perlu mempertimbangkan beragam aspek. Page (2019) menyebutkan bahwa untuk 
mengantisipasi dampak buruk pariwisata serta untuk memberikan pengalaman wisata yang maksimal kepada para wisatawan, maka pengelola atau pengembang perlu menyeimbangkan kebutuhan wisatawan, keadaan destinasi atau lingkungan, serta kepentingan para pelaku parwisata.

Proses tersebut kemudian dikenal dengan istilah visitor management. Eagles, Paul, dan McCool (2002) mendefinisikan visitor management sebagai sebuah tindakan administratif yang bertujuan untuk menjaga kualitas destinasi dan pengalaman wisata wisatawan (Candrea \& Ispas, 2009). Definisi tersebut jelas menunjukkan bahwa visitor management merupakan suatu upaya untuk mengantisipasi dampak buruk pengembangan pariwisata, khususnya efek buruk terhadap pelestarian lingkungan. Selain memperhatikan faktor lingkungan atau kualitas destinasi yang dimiliki, pihak pengelola yang menerapan visitor management juga berusaha dalam memberikan pengalaman wisata yang optimal, menyenangkan, dan berkesan kepada wisatawan.

Dalam merencanakan visitor management, terdapat tiga tahapan penting, yaitu tahap persiapan, tahap pengembangan, dan tahap implementasi dan pemasaran (El-Barmelgy, 2013).

a. Tahap persiapan

Tahap persiapan merupakan tahapan penting dalam melakukan visitor management. Pada tahap ini dilakukan identifikasi masalah serta potensi pemecahan yang dapat dilakukan. Pada tahap ini juga seluruh pelaku wisata yang terlibat menyatukan suara dan berkomitmen untuk menyukseskan visitor management.

b. Tahap pengembangan

Tahap kedua adalah pengembangan yang merupakan tahap merancang seluruh mekanisme dan prosedur yang nantinya akan diimplementasikan di suatu destinasi wisata. c. Tahap implementasi

Tahap terakhir adalah implementasi dimana mekanisme, prosedur, dan peraturan yang dikembangkan diimplementasikan secara langsung. Pada proses ini juga dilakukan evaluasi untuk melihat efektifitas dan masalah yang muncul dalam implementasi.

El-Barmegly (2013) juga menyebutkan tujuh faktor penentu keberhasilan suatu visitor management, yaitu sebagai berikut.

a. Keterlibatan pelaku wisata dan pemilik modal

b. Adanya proses inventarisasi dan riset

c. Tim yang tergabung dalam proses perencanaan hingga implementasi visitor management

d. Sumber daya yang cukup

e. Memiliki pemimpin yang cakap

f. Proses pengelolaan dan monitoring

g. Pemasaran yang efektif dan baru Candrea \& Ispas (2009) menyarankan beberapa teknik visitor management yang dapat diaplikasikan destinasi wisata, khusus daerah yang dilindungi.

a. Mengatur akses wisata berdasarkan wilayah atau zonasi,

b. Mengatur kunjungan sesuai dengan jenis pengunjung,

c. Menetapkan biaya masuk bagi wisatawan,

d. Menyediakan fasilitas dan program interpretasi,

e. Menetapkan kode etik pengunjung,

f. Fokus pada memberikan izin hanya kepada organisasi terpercaya dalam membawa wisatawan.

Itulah teknik yang dapat dilakukan oleh pengelola destinasi wisata untuk menerapkan visitor management guna menjaga kualitas wilayah serta memberikan pengalaman wisata yang maksimal kepada wisatawan atau pengunjung. Salah satu negara yang berhasil menerapkan visitor management yang ketat adalah Bhutan. Bhutan menerapkan peraturan yang sangat ketat untuk menjaga kualitas alam dan hidupa masyarakat serta pengalam wisata para pengunjung. Bhutan membatasi jumlah 
wisatawan yang datang berkunjung. Backpackers atau pelancong solo tidak dapat memasuki area Bhutan. Bhutan sangat menyadari bahwa aset wisata yang mereka miliki adalah kekayaan alam dan budaya sehingga mereka berusaha untuk menjaga kelestarian alam dan budaya dan pada saat yang bersamaan juga mengembangkan sektor pariwisata.

\section{KESIMPULAN}

Pariwisata yang saat ini tengah berkembang memiliki dua sisi yang berjalan beriringan. Sisi positif dan sisi negatif pariwisata tidak dapat dipisahkan. Kedua sisi atau dampak tersebut secara langsung mempengaruhi sektor pariwisata, kehidupan sosial dan budaya masyarakat, serta pelestarian lingkungan. Tiga sektor tersebut memperoleh imbas yang nyata dari pengembangan pariwisata. Dalam sektor ekonomi, pariwisata memberikan dampak yang positif berupa kontribusi pada devisa negara maupun pada perekonomian negara. Namun perlu diperhatikan kepemiliki sektor swasta dalam dunia pariwisata. Kecenderungan pemilik yang berasal dan luar daerah atau luar negeri akan membawa seluruh pendapatan dan keuntungan ke daerah atau negara asalnya. Masyarakat lokal hanya menikmati sedikit dari hasil tersebut. Inilah yang mendorong adanya kebocoran ekonomi akibat pariwisata. Dari segi kehidupan sosial dan budaya, dunia pariwisata juga memberikan dampak positif dan negatif. Dampak negatif pariwisata terhadap kehidupan sosial dan budaya tanpa sadari telah mengubah gaya hidup, cara pandang masyarakat lokal. Selain dua ranah tersebut, pariwisata juga berkontribusi dan bertanggung jawab terhadap kerusakan alam yang ditimbulkannya.

$\begin{array}{ccr}\text { Untuk mengantisipasi } & \text { dan } \\ \text { menanggulangi } & \text { dampak } & \text { negatif }\end{array}$
pemerintah, maupun pelaku wisata perlu menyeimbangkan antara kebutuhan wisatawa, pelestarian lingkungan, kebutuhan pelaku wisata, pengelola destinasi, dan pemerintah tanpa mengesampingkan kualitas pengalaman wisata yang diberikan kepada wisatawan. Visitor management merupakan salah satu langkah yang dapat ditempuh oleh pengelola destinasi, pemerintah dan pelaku wisata dalam mengelola seluruh sumber daya yang ada guna tetap mengembangkan pariwisata secara bijak dan bertanggung jawab.

\section{PERNYATAAN PENGHARGAAN}

Penulis ingin mengucapkan terima kasih kepada seluruh pihak yang telah memberi dukungan sehingga artikel ilmiah ini dapat diselesaikan dengan baik.

\section{DAFTAR PUSTAKA}

Candrea, A. \& Ispas, A., (2009). Visitor Management, A Tool For Sustainable Tourism Development In Protected Areas. Bulletin of the Transilvania University of Braşov, 2(51).

El-Barmelgy, E. M., (2013). Visitor Management Plan and Sustainable Culture Tourism. International Journal of Education and Research, 1(12).

Hall, M. C. \& Lew, A. A., (2009). Understanding and Managing Tourism Impacts. Oxon: Routledge

Ibnou-Laaroussi, S., Rjoub, H. \& Wong, W.-K., (2020). Sustainability of Green Tourism among International Tourists and Its Influence on the Achievement of Green Environment: Evidence from North Cyprus. Sustainability, Volume 12.

Kumar, J., Husain, K. \& Kanann, S., (2015). Positive Vs Negative Economic Impacts of Tourism Development: A Review of Economic Impact Studies. Kuala Lumpur, APTA.

Nunes, L. J., Raposo, M. A. \& Gomes, C. J., (2020). The Impact of Tourism Activity on Coastal Biodiversity: A Case Study at Praia da Cova Redonda (Algarve-Portugal). Sustainability.

Page, S. J., (2019). Tourism Management. Oxon : Routledge. 
Mulia

United Nations World Tourism Organization. (2016). Glossary of Tourism Terms. https://www.unwto.org/glossarytourism-terms

Urbanus, I. N. \& Febianti, (2017). Analisis Dampak Perkembangan Pariwisata Terhadap Perilaku Konsumtif. Jurnal Kepariwisataan Dan Hospitalitas, 1(2).

Tovmasyan, G. (2016). Tourism development trends in the world. European Journal of Economic Studies, Vol. 17. Accessed at March 28, 2021 at https://www.researchgate.net/public ation/323748083_Tourism_developm ent_trends_in_the_world_httpselibrar yruitemaspid27207616

Wiranatha, A. S., Antara, M. \& Suryawardani, I. G. A. O., (2015). Impact of Tourism Leakage on the Growth of Economic Sectors,Employment and Income Distribution in Bali, Indonesia. International Journal of Economic Research.

World Tourism Organization (UNWTO); Cente of Expertise Leisure, Tourism \& Hospitality; NHTV Breda University of Applied Sciences; and NHL Stenden University of Applied Sciences (2018), 'Overtourism'? - Understanding and Managing Urban Tourism Growth beyond Perceptions, Executive Summary, UNWTO, Madrid, DOI:

https://doi.org/10.18111/97892844 20070.

World Travel \& Tourism Council, (2020). Economic Impact Reports. [Online] Available at: https://wttc.org/Research/Economic -Impact

Zhuang, X., Yao, Y. \& Li, J., (2019). Sociocultural Impacts of Tourism on Residents of World Cultural Heritage Sites in China. Sustainability.

MEMAHAMI DAN MENGELOLA

DAMPAK PARIWISATA 